\title{
МИКРОБИОМ, МИКРОБИОТА
}

\section{ЧТО НОВОГО?}

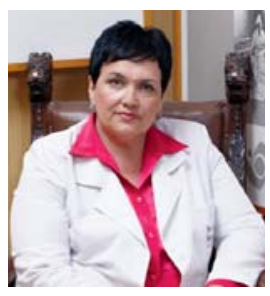

\begin{abstract}
Последнее десятилетие в области изучения микрофлоры человека открыло во всем многообразии удивительный и густонаселенный мир микроорганизмов. Сегодня ученые считают устаревшим термин «микрофлора», предлагая более широкое понятие под названием «микробиом». Мы обратились к профессору, заведующей кафедрой педиатрии ГБОУ ВПО РМАНПО МЗ РФ, главному педиатру ЦАО Ирине Николаевне Захаровой с просьбой рассказать о новых тенденциях в области изучения микробиома и его влиянии на человека.
\end{abstract}

- Уважаемая Ирина Николаевна, скажите, пожалуйста, что нового известно сегодня о кишечной микрофлоре?

- История изучения кишечной микробиоты насчитывает более трех столетий. Еще в 1681 г. Антони ван Левенгук (рис. 1) изобрел примитивное приспособление, с помощью которого он обнаружил микроорганизмы в фекалиях, и выдвинул гипотезу о совместном существовании различных видов микроорганизмов в желудочнокишечном тракте (ЖКТ).

В 1850 г. Луи Пастер создал теорию о функциональной роли бактерий в процессе пищеварения, а Р. Кох продолжил исследования в этом направлении и разработал методику разграничения болезнетворных и полезных микроорганизмов.

Учение о роли симбионтной микрофлоры в организме человека связано с именем великого русского ученого, лауреата Нобелевской премии И.И. Мечникова, который в 1888 г. обосновал теорию о том, что в кишечнике человека обитает комплекс микроорганизмов, оказывающих на организм «аутоинтоксикационный эффект» (рис. 2). Он полагал, что введение в ЖКТ «здравословных» бактерий способно стабилизировать действие кишечной микрофлоры и противодействовать интоксикации. Существенный вклад в изучение микрофлоры человека внес немецкий ученый Альфред Ниссле, который с 1912 г. активно занимался изучением бактерий. Им же в 1916 г. был впервые введен термин «дисбактериоз». «Второе

\section{Рисунок 1. Антони ван Левенгук (1632-1723)}
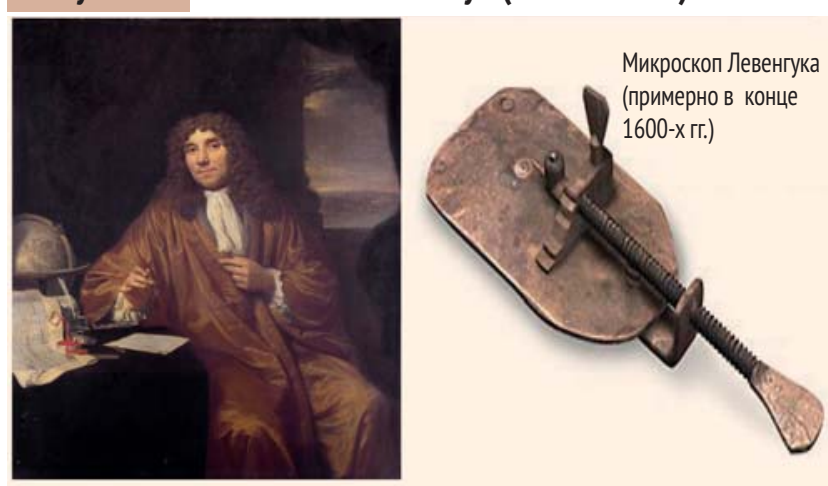

«Я нашел, к моему большому удивлению, что он содержал много мельчайших микроскопических организмов, за движениями которых было очень приятно наблюдать» дыхание» учение о кишечной микрофлоре получило уже в 70-е гг. XX в., во многом благодаря работам советского ученого А.М. Уголева, который определил дисбактериоз кишечника как изменение качественного и количественного состава бактериальной его флоры, возникающее под влиянием различных факторов: питания, изменения перистальтики кишечника, возраста, воспалительных процессов, лечения антибактериальными препаратами, стресса, тяжелых соматических заболеваний (рис. 3).

- Ирина Николаевна, а что изменилось в современной трактовке понятия «микрофлора кишечника»?

- Изменилась терминология. Мы не говорим о микрофлоре, поскольку термин «флора» устаревший: растительный мир. Микроорганизмы (бактерий, грибов, вирусов), обитающие внутри и снаружи человека, называют микробиомом. Новая эпоха в изучении кишечного микробиома наступила 5-10 лет назад и связана с появлением молекулярно-генетических методов исследования, буквально перевернувших все наши старые представления. Мы живем в удивительное время, когда с приходом новых технологий меняются наши старые знания, в т. ч. о здоровье и болезни. Сегодня пришло абсолютно новое понимание необходимости микроорганизмов (микробиома) внутри и снаружи нашего организма, имеющее большое значение не только для нашего пищеварения, но и всего тела и головного мозга, нашего здоровья в целом.

- Как с позиции современных положений рассматривают микробиом, чем он отличается от микробиоты?

- Термин «микробиом» был впервые внедрен в 2001 г. для обозначения коллективных геномов микробиоты. Микробиом представляет собой сообщество бактерий, которое каждый из нас имеет внутри и снаружи своего тела. Микробиом каждого человека является уникальным для него и содержит в десятки раз больше клеток и в 100 раз больше генов, чем собственных генов человеческого организма. Вес микробиома зависит от массы тела и составляет от 1,2 до 3,5кг. Наш микробиом регулирует многие жизненно важные процессы организма и даже оказывает влияние на поведение человека! Микробиом считают еще одним органом человека (рис. 4). Появляется заманчивая идея: а что если поменять свой микробиом 
Рисунок 2. Илья Ильич Мечников (1845-1916). Динамика роста числа научных публикаций, посвященных изучению пробиотиков

\section{Сто лет концепции пробиотиков}

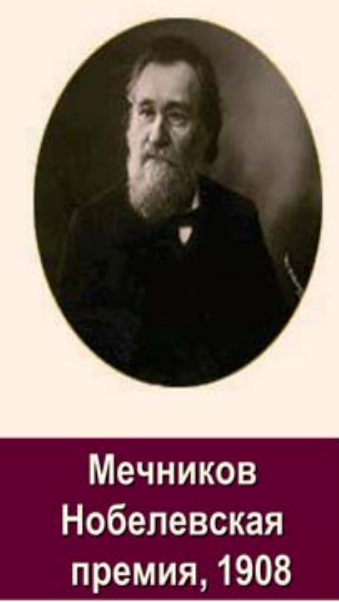

Благодаря современным научным исследованиям в области генетики ученые смогли идентифицировать и определить количество микроорганизмов, живущих в человеческом организме. С помощью новейших научных разработок удалось установить, что существует более 1100 видов микроорганизмов, большинство которых анаэробы. Ученые имеют много доказательств тому, что чем более разнообразны кишечные микроорганизмы, тем лучше здоровье человека, а низкое разнообразие связано с различными болезнями.

Активное внедрение молекулярно-генетических технологий в практику микробиологических исследований позволило получить новую информацию о составе и свойствах интестинальной микробиоты у людей разного возраста. Разработан целый арсенал методов исследования, (с помощью диеты, образа жизни, медицинских манипуляций), может быть, это окажет влияние на здоровье человека в целом и позволит решить целый ряд проблем с ним? Микробиота - это термин, который используется для характеристики микробиоценоза отдельных органов и систем. Например, микробиота кишечника, микробиота кожи, микробиота плаценты, микробиота грудного молока и т.д.

А что же происходит на самом деле? По инерции педиатры продолжают рекомендовать проводить культуральные исследования кала, которые перестали делать во многих странах еще 7-8 лет назад! К недостаткам культурального метода исследования фекалий следует отнести дороговизну, длительность и трудоемкость выполнения методики, зависимость результата от техники сбора, вариабельность нормы, низкую разрешающую способность (100 жизнеспособных бактериальных клеток), а главное - большинство микроорганизмов в кале являются некультивируемыми!

Изменения в микробиоме человека и отдельных его локусов, могут быть связаны с синдромом раздраженного кишечника, бронхиальной астмой, пищевой аллергией, воспалительными заболеваниями кишечника (язвенный колит, болезнь Крона), аутоиммунными заболеваниями, сахарным диабетом 2-го типа, атеросклерозом, целиакией, заболеваниями печени, ранним детским аутизмом, болезнью Паркинсона, некоторыми видами рака, депрессией, шизофренией. Отсюда мы понимаем тот интерес, который появился не только у гастроэнтерологов, но и у врачей разных специальностей - кардиологов, онкологов, эндокринологов, психиатров и других специальностей, к этой проблеме! Появились перспективные исследования, направленные на оптимизацию микробиома кишечника для восстановления здоровья человека.
Рисунок 3. История изучения кишечной микробиоты, появление термина «дисбактериоз». Альфред Ниссле и Александр Михайлович Уголев
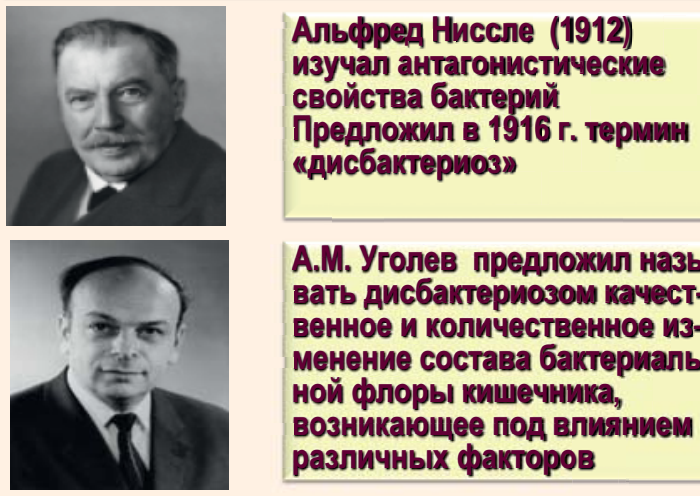

Альфред Ниссле (1912) изучал антагонистические свойства бактерий Предложил в 1916 r. термин "дисбактериоз"

A.M. Уroneв предложил называть дисбактериозом качественное и количественное изменение состава бактериальной флоры кишечника, возникающее под влиянием различных факторов

Рисунок 4. Международные исследования микробиоты человека

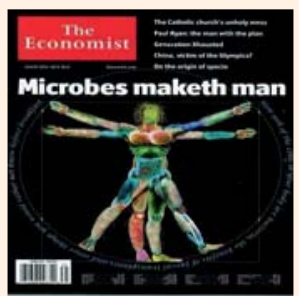

- 2 международных проекта по исследованию микробиоты человека (геномные исследования) - NIH (USA) u MetaHIT (EU) Изменение взгляда на микробиоту человеческого организма как на жжизненных партнеров»: «...that humans are not single organisms, but superorganisms made up of lots of smaller organisms working togethern 
Рисунок 5. Данные Национального института США о клеточном разнообразии человеческого организма

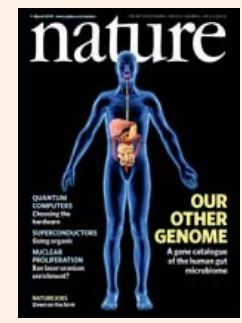

Согласно данным Национального института здоровья США, только $10 \%$ клеток, которые входят в состав человеческого организма, являются собственно человеческими клетками. Остальные $90 \%$ принадлежат бактериям, населяющим различные биотопы человека

\section{Homo sapiens moжem быmb оnucar кан "суперореанизми, в котором сосуиестауует большое количестео различных ореанизмов}

Turnbaugh PJ, Ley RE, Hamady M, Fraser-Liggett CM, Knight R, Gordon JI. The human microbiome project. Nature 2007; 449 (7164): 804-810.

Goodacre R. Metabolomics of a superorganism. J Nutr 2007; 137(1 Suppl): 259S-266S 5.

позволяющих не только быстро и достоверно определить видовую принадлежность выделяемых микроорганизмов, но и проводить их количественную оценку непосредственно в исследуемом материале без этапа культивирования. С внедрением метода секвенирования ДНК (1999) - определения нуклеотидной последовательности генов $16 \mathrm{~S}$ РНК - удалось установить, что только 7-10\% микроорганизмов, живущих в кишечнике, культивируются. Это значит, что наши старые представления о микробиоте кишечника устарели. Метод секвенирования ДНК позволил установить, что в кишке живет более тысячи видов микроорганизмов, 99\% из них - это анаэробы, состав которых существенно отличается от того, который ранее представлялся по данным культуральных исследований. Согласно данным Национального института здоровья США (National Institutes of Health, NIH), только 10\% клеток, входящих в состав человеческого организма, являются собственно человеческими клетками, а остальные 90\% принадлежат бактериям, населяющим различные биотопы человека. Таким образом, homo sapiens является «суперорганизмом», в котором сосуществует большое количество различных организмов (рис. 5). В 2008 г. был запущен глобальный проект «Микробиом человека» (НМР), ставивший своей целью расшифровку генома бактерий, населяющих организм человека. Расшифровкой генома бактерий, населяющих ЖКТ, занимается Европейский консорциум MetaHIT. Уже расшифровано около 3 млн генов, что примерно в 150 раз больше набора генов человека. Результаты проекта позволят попытаться установить взаимосвязь этих генов, состояния здоровья человека, развития заболеваний и фенотипа. В 2010 г. в исследование метагенома человека также активно включились российские ученые. По мнению журнала Science, расшифровка метагенома человека входит в число величайших научных открытий последнего десятилетия (рис. 6).

Ученые, с учетом состава, разделили микробиоты на энтеротипы, каждый из которых включает много различных видов микроорганизмов вне зависимости от места проживания, состояния здоровья или возраста. Исследо- ватели объединили популяции бактерий в кластеры, названные согласно доминирующим в них родам. Данное открытие можно сравнить с делением людей на группы крови. Bacteriodes является доминирующим у первого энтеротипа, Prevotella преобладает у второго энтеротипа, a Ruminococcus - у третьего. Позднее были выделены и другие энтеротипы. Так, энтеротип Bacteroides отличается активностью в отношении разложения углеводов, а также

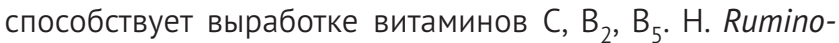
coccus, наоборот, улучшает всасывание углеводов и повышает уровень сахара в крови, а также синтезирует фолиевую кислоту и витамин $\mathrm{B}_{1}$. Prevotella в процессе жизнедеятельности разрушает защитный слизистый покров, что, вероятно, предрасполагает к дефектам слизистой оболочки кишечника. Следовательно, наличие определенного энтеротипа позволит прогнозировать особенности обмена веществ и указывать на предрасположенность к определенным заболеваниям. В то же время использование такого диагностического метода, как ПЦР, показало, что микробиота кишечника каждого человека индивидуальна и постоянна.

С нарушенной микробиотой кишечника ассоциируется широкий спектр заболеваний: инфекции, диарея, язвенная болезнь, рак желудка и рак толстой кишки, ожирение, мальабсорбция, сахарный диабет, пищевая аллергия, бронхиальная астма, воспалительные заболевания кишечника, кишечная колика, синдром раздраженного кишечника, поведенческие нарушения. Это обусловлено тем, что нормальная микробиота кишечника участвует в разнообразных физиологических функциях организма: защитной, пищеварительной, детоксикационной и антиканцерогенной, синтетической, генетической, иммуногенной, в регуляции обмена холестерина и оксалатов.

- Ирина Николаевна, а что определяет состав микробиоты у новорожденных детей?

- Прежде всего, микробиота младенца зависит от кишечной микробиоты матери, а также от окружающей

\section{Рисунок 6. Проект «микробиом человека»}

С 2008 г. начат глобальный проект кмикробиом человекаш (HМP), ставивший своей целью расшифровыу генома бактерий, населяющих организм человека. Термин пмикробиомы был впервые внедрен в 2001 r. Аля обозначения коллективных геномов микробиоты

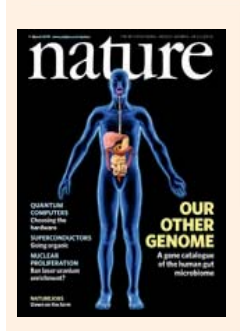
Расшифровкой генома бактерий,
населяющих ЖКТ, занимается
Бвропейский консорциум МеtаНІт,
Расшифровано Около 3 мЛн генов, что
примерно в 150 раз больше набора
генов человека
РАСШИФРОВКА МЕТАГЕНОМА
ЧЕЛОВЕКА ВХОДИТ В ЧИСЛО
ВЕЛИЧАЙШИХ НАУЧНЫХ ОТКРЫТИЙ
ПОСЛЕДНЕГО ДЕСЯТИЛЕТИЯ! Qin et al. Nature 2010;464:59-65. 
среды и питания новорожденного. Мать является первым источником колонизации и инфицирования своего ребенка. Состояние ее микробиоты определяется способом родоразрешения (роды естественные, оперативные), местом проведения родов (родильный дом, квартира, поскольку в некоторых странах физиологические роды осуществляются в домашних условия). Микробиота желудочно-кишечного тракта младенца зависит от состояния кожи, родовых путей и кишечника родильницы, от того, применялась ли антибактериальная терапия у матери и ребенка. Существенное значение имеет время прикладывания к груди, характер вскармливания с рождения. Так как заселение микроорганизмами слизистых новорожденного начинается с момента прохождения его через родовые пути, то естественный способ родоразрешения является одним из основополагающих, влияющих на формирование микробиоты. Однако заселение кишечника плода микроорганизмами закладывается уже во второй половине беременности от матери (по данным зарубежных и отечественных исследований, до 22-й недели гестации микробов в организме плода нет вообще, а начиная с 24-й недели появляются единичные колонии кишечной палочки и лактобацилл в кишечнике плода). Большую роль в формировании микробиоты кишечника плода играют питание, образ жизни матери, а также факт приема антибактериальных препаратов во время беременности, что может нарушить ее баланс.

Сегодня мы располагаем достоверными данными о составе микрофлоры влагалища роженицы, которая в большей степени заселена лактобактериями (более $60 \%)$, энтерококками, стафилококками и грибковой бактерией кандида, поэтому младенцы, рожденные естественным путем имеют флору, напоминающую влагалищную флору матери с преобладанием лактобацилл, а рожденные путем кесарева сечения - флору, подобную флоре кожи матери - больше стафилококков и пропионовых бактерий.

\section{Питание новорожденного, а именно раннее прикладывание к груди и обеспечение естественного вскармливания - один из главных факторов, влияющих на правильное формирование микробиоты кишечника малыша}

Современный мир озабочен ростом числа родов путем кесарева сечения, в развитых странах это составляет порядка 30-40\%, что позволяет наблюдать практически вертикальный рост частоты аллергии у детей раннего возраста, связанный с этим фактом. У ребенка, родившегося путем кесарева сечения, т.е. неестественным, нефизиологическим путем, происходит задержка микробной колонизации, ребенок не получает «микробного удара» В момент родов, что резко увеличивает риск развития аллергии.

Если определить факторы окружающей среды, влияющие на формирование микробиоты новорожденного, то существенную роль играют совместное пребывание малыша с мамой после родов, был ли ребенок переведен в реанимационное отделение, как долго продолжалось его пребывание в стационаре. Например, в Нидерландах и еще ряде стран Европы для создания наиболее благополучной атмосферы окружающей среды родоразрешение проводится на дому. Конечно, весь процесс планируется заранее, и проводят исключительно с участием бригады медицинских сотрудников. Такие роды вполне успешны, а главное - это дает возможность избежать заселения госпитальной флорой.

\section{Микробиота желудочно-кишечного тракта младенца зависит от состояния кожи, родовых путей и кишечника родильницы, от того, применялась ли антибактериальная терапия у матери и ребенка. Существенное значение имеет время прикладывания к груди, характер вскармливания с рождения}

И наконец, питание новорожденного, а именно раннее прикладывание к груди и обеспечение естественного вскармливания - один из главных факторов, влияющих на правильное формирование микробиоты кишечника малыша.

- Почему для формирования микробиоты именно грудное вскармливание так необходимо новорожденному?

- Благодаря исследованиям, проведенным в последние 10 лет, с использованием метода секвенирования, мы узнали, что грудное молоко вовсе не стерильно, как предполагалось ранее, а, наоборот, содержит до 700 различных микроорганизмов. Они попадают в материнское молоко из кишечника путем бактериальной транслокации в кровоток, минуя лимфатические узлы. Конечно, осталось множество вопросов, как этот процесс осуществляется, но факт наличия большого количества микроорганизмов в материнском молоке доказан. Соответственно, молоко матери также способствует колонизации кишечника и правильному формированию микробиоты младенца.

- Ирина Николаевна, а существует ли зависимость формирования микробиома ребенка от социального уровня страны или семьи в отдельности?

- Да, существует зависимость формирования микробиоты ЖКТ новорожденного от его социального уровня. Показано, что у младенцев, родившихся в бедных странах, например в Пакистане, Нигерии, Индии, где женщины иногда рожают буквально в канаве, колонизация кишечника ребенка бактериями происходит очень рано, и уже в течение первых дней жизни из его фекалий начинают выделяться энтеробактерии. Мы знаем, что в бедных странах практически нет проблемы аллергии. Однако в Европе аллергия сейчас занимает первое место, особенно у немцев. В Швеции 25\% детей не имеют энтеробактерий в стуле через неделю пребывания в роддоме, а в США 35\% детей не колонизировали кишечник в течение первых 2 недель жизни. 
- Огромное количество факторов влияет на формирование микробиоты желудочно-кишечного тракта. А каковы последствия ее изменения в течение жизни?

- Человеческий организм представляет собой суперорганизм, который населен огромным количеством микроорганизмов, причем около 20\% того, что употребляет в пищу человек, идет на кормление этих микробов. У каждого локуса своя флора, все зависит от места расположения, возраста и состояния здоровья. Да, кишечная микробиота - это, конечно, не нечто неизменное, она представляет собой динамически меняющуюся смесь микробов, типичных для каждого человека. Но необходимо помнить, что смена флоры может приводить к болезням. Поэтому сейчас весь мир изучает связь болезней с микробиотой, и уже доказано, что изменения микробиома приводят к аллергии, аутоиммунным, сердечно-сосудистым, метаболическим и психиатрическим заболеваниям. Потрясающие работы сейчас проводятся в СанктПетербурге, в Военно-медицинской академии, по выявлению связи микробиоты с инсультами и инфарктами. Установлено, что микробиота реализует свои функции через микробно-тканевой комплекс.

- Ирина Николаевна, можно ли как-то корригировать микробиоту желудочно-кишечного тракта?

- Существует три основных варианта воздействия на микробиоту: это применение антибактериальных препаратов, пребиотиков и пробиотиков. Многие специалисты пытаются скорректировать микробиоту антибиотиками, и, к сожалению, в нашей стране накоплен богатейший негативный опыт по уничтожению микробиоты кишечника гентамицином. Когда мы обсуждаем назначение пребиотиков, то необходимо помнить, что это «удобрения», на которых могут вырасти абсолютно любые микроорганизмы. Конечно, совсем другое дело при их дифференциации на селективные и неселективные. Более полезными являются селективные, стимулирующие рост полезной микрофлоры. Если мы применяем для восстановления микробиома пробиотики, то мы знаем, что существуют тысячи штаммов микроорганизмов и каждый штамм предназначен для лечения конкретной патологии. Все пробиотики делятся на бифидо-, лакто-, сахаромицеты, они работают на уровне собственной пластинки, эпителия слизистой. В настоящее время назначение пробиотиков надо проводить с учетом штаммоспецифичности. Например, для профилактики антибиотик-ассоциированной диареи самая высшая степень доказательности у сахаромицет (препарат Энтерол) и лактобацилл GG (LGG) (препараты Нормобакт L и Према).

- Ирина Николаевна, сегодня пищевая аллергия у детей стала одной из самых распространенных патологий. Может ли применение пробиотиков помочь в лечении аллергии?

- Да, сегодня мы активно используем при ведении детей с аллергией пробиотик на основе LGG, с антиаллергическим эффектом, занимающий первое место среди других. Существует множество исследований, которые доказали, что применение LGG способствует купированию аллергического воспаления в кишечнике и снижению фактора некроза опухоли-альфа на уровне кишки. Поэтому, когда мы имеем дело с ребенком, которого беспокоят боли и вздутие живота, помимо элиминационной диеты, необходимо назначение LGG вместе с питанием (например, йогурты, другие кисломолочные продукты), что приводит к быстрому положительному эффекту. LGG имеет очень хорошую адгезию, устойчивость к кислоте, желчи и ферментам, правда, он разрешен к применению только с месячного возраста. Также пробиотик на основе LGG влияет на синтез интерлейкина-10, что позволяет успешно применять его в реабилитации часто болеющих детей и для нормализации иммунологического дисбаланса при аллергии. Препараты на основе LGG подтвердили высокую эффективность при лечении атопического дерматита у детей с отягощенной наследственностью по аллергии, поэтому я всегда использую препараты на основе LGG у своих пациентов.

\section{Различные типы диет по-разному влияют на обмен информачией по оси «кишечник - мозг». Например, диеты с высоким содержанием жира способны провоцировать механизмы негативного влияния на мозг}

Если у ребенка установлена нетяжелая непереносимость лактозы, можно рекомендовать йогурты, поскольку закваски с включением LGG дают хороший эффект.

Кроме того, LGG обладает противомикробным, противовирусным и противогрибковым действием.

- Возможно ли при помощи питания, особенно детей младшего возраста, которые уже не употребляют материнское молоко, а переходят на продукты питания промышленного производства, поддерживать необходимый баланс микробима?

- Да, конечно, приветствуется ежедневное употребление кисломолочных продуктов, в т. ч. содержащих пробиотические культуры, с помощью которых можно воздействовать на микробиом кишечника. Сегодня мы имеем возможность включать в рацион детей специально разработанные кисломолочные продукты из натуральных ингредиентов, дополнительно обогащенных кальцием и витамином Д, с учетом роста и развития ребенка. Важно отметить, что современные технологии позволяют создавать их без консервантов и искусственных красителей, снижая риск развития аллергии.

- Ирина Николаевна, и главный вопрос: есть ли связь между состоянием микробиоты кишечника и деятельностью головного мозга?

- Безусловно, на сегодняшний день нет сомнений в том, что кишечник и мозг не только связаны между собой, но и активно взаимодействуют. Появились экспериментальные исследования на животных, а также 
клинические наблюдения, доказывающие эту связь. В принципе, здесь нет ничего нового. Все давно знают, что если у человека стресс, то в первую очередь часть из нас почувствует его последствия со стороны кишечника, например, появятся позывы идти в туалет. Или у ребенка, испытывающего стресс, связанный с походом в детское дошкольное учреждение, в новый класс, может развиться запор. Так, Emeran Mayer, анализируя различные типы взаимодействия, обмена информацией по оси «кишечник - мозг», как сверху вниз, так и снизу вверх, говорит о различных способах этого взаимодействия: через гормоны, нервные импульсы, а также через сигнальные молекулы иммунных клеток. Отдельно анализируется вклад кишечной микробиоты в обмен информацией между кишечником и мозгом. Одной из основных реакций микробиоты на эмоции, стресс своего хозяина, по-видимому, является изменение количества производимых ими метаболитов. Самым важным периодом жизни является ранний период, начиная с внутриутробного этапа и в первые три года жизни ребенка, когда формируются микробный состав кишечника и основные нейронные связи мозга. Перспективные исследования на грызунах показали, что микробиота кишечника способна оказывать влияние на повседневные эмоции, а возможно, и определять, насколько длительными или сильными будут эти эмоции. Важную роль в формировании микробиоты кишечника играет питание (диета), в т. ч. в формировании связи «кишечник - мозг». Различные типы диет по-разному влияют на обмен информацией по оси «кишечник - мозг». Например, диеты с высоким содержанием жира способны провоцировать механизмы негативного влияния на мозг. В этой связи рекомендуется ограничить количество жиров животного происхождения в своем рационе и потреблять больше ферментированных продуктов.
В последние годы становится больше детей с расстройствами аутистического спектра. Проведенные эпидемиологические исследования показали, что ожирение у матери во время беременности может увеличить риск развития расстройств нервной системы, в т. ч. расстройств аутистического спектра у ребенка. У детей с этими расстройствами часты проблемы с желудочно-кишечным трактом. Исследователи пытались выявить связь между изменениями в рационе питания, микробиомом и социальным поведением и сделали вывод о том, что диета матери с высоким содержанием жиров может привести к дисбиозу кишечника у потомства и вызывать поведенческие расстройства, которые могут быть скорректированы с помощью селективного введения штаммов L. Reuteri. Расстройства пищеварения, которые наблюдаются у пациентов с расстройствами аутистического спектра, могут быть связаны с их более высокой раздражительностью, агрессивным поведение и нарушениями сна. Появилась гипотеза о том, что один из способов изменить пищевое поведение - изменение состава кишечной микробиоты. Исследование, проведенное профессором Г. Фростом из Лондона, подтвердило, что пропионат, производимый бактериями толстой кишки, способен влиять на механизм «еда - удовольствие» и пищевое поведение хозяина. Последние открытия в области микробиоты подтвердили ее важность для осуществления взаимодействия между центральной и энтеральной нервной системой. Эти взаимодействия по оси «кишечник - мозг», по всей видимости, осуществляются в двух направлениях с помощью нейронных, эндокринных, иммунных и гуморальных сигналов.

- Уважаемая Ирина Николаевна, благодарим Вас за чрезвычайно интересную и познавательную беседу.

\section{Беседовала ЮлИя ЧЕРЕДНИЧЕНКО}

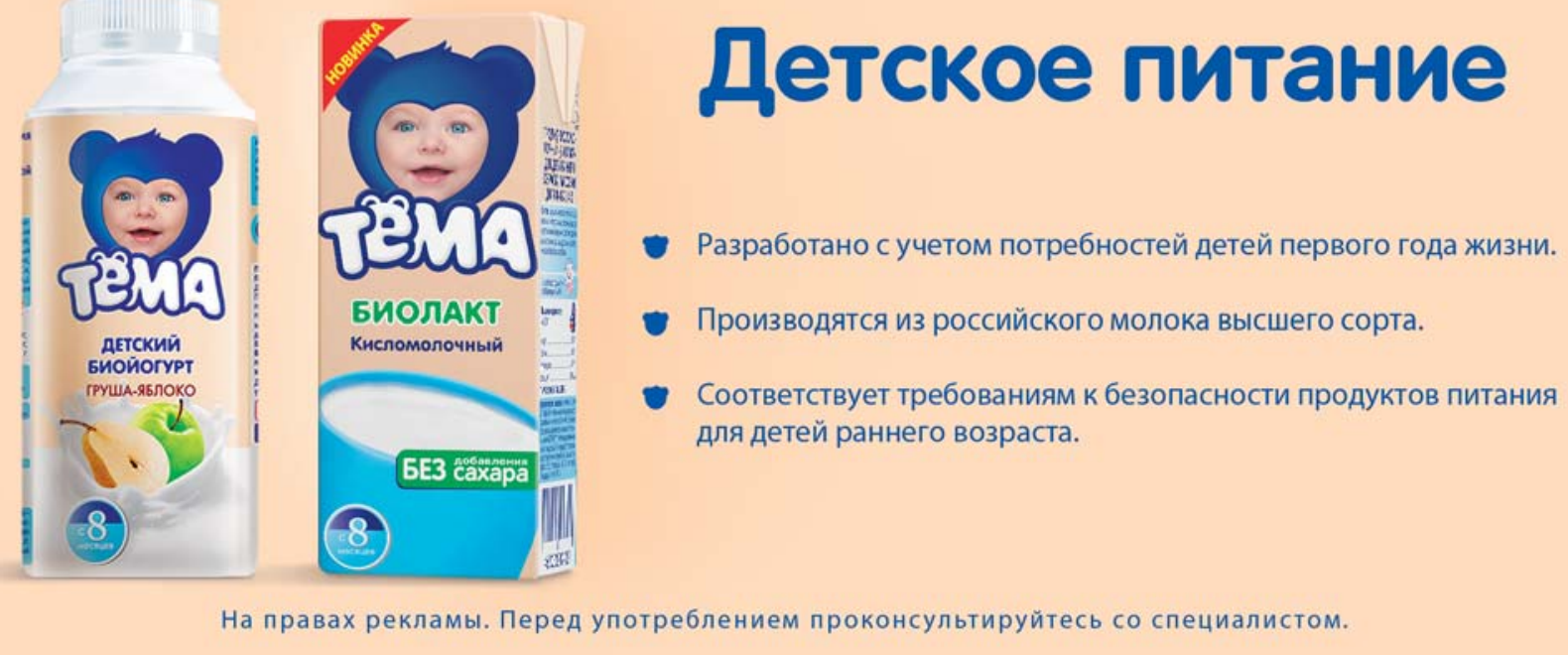

